\title{
PENGARUH PERAN BUDAYA ORGANISASI, EFEKTIVITAS KEPEMIMPINAN DAN MOTIVASI KERJA PEGAWAI TERHADAP KEBIJAKAN BADAN LAYANAN UMUM
}

\author{
Azis Ritonga \\ Politeknik Kesehatan Jakarta III Kementerian Kesehatan \\ sanurabadi@yahoo.com
}

\begin{abstract}
The background of this research is the change of status of Health Polytechnics of Surakarta from Civil Servant purely become Public Service Agency. Where in this form change make Health Polytechnics of Surakarta prepare their own budget. Thus there must be a change of management to address it. For that researchers are very interested to see the effect of Organizational Culture Roles, Leadership Effectiveness And Employee Motivation Against Public Service Agency Policy. The population in this research is all employees of Health Polytechnics of Surakarta. This research uses Simple random sampling which is a randomly chosen sampling technique. Statistical analysis using structural equation model (SEM). With 95\% confidence level of research results showed that there is no significant positive relationship between organizational culture and leadership in Health Polytechnics of Surakarta.There is no significant correlation between organizational culture on policy of Health Polytechnics of Surakarta Public Service Agency (BLU).There is no significant correlation between work motivation toward leadership in Health Polytechnics of Surakarta.There is no significant correlation between work motivation to BLU policy in Health Polytechnics of Surakarta.There is no significant positive correlation between leadership of BLU policy in Health Polytechnics of Surakarta
\end{abstract}

Keywords: Organizational Culture Roles, Leadership Effectiveness And Employee Motivation Against Public Service Agency Policy

\section{LATAR BELAKANG}

Pelayanan publik di negara kita masih sering diidentikkan dengan ketidakpastian baik dalam hal biaya, waktu dan prosedur. Masyakarat sebagai warga pengguna pelayanan seringkali mengeluhkan buruknya pelayanan para birokrat diorganisasiorganisasi penyelenggara pelayanan. Para pengguna layanan jarang sekali diperlakukan sebagai warga negara yang memiliki kedaulatan atas pemerintah dan birokrasinya atau sebagai pelanggan yang dapat menentukan nasib penyelenggara layanan (Dwiyanto, 2010) Lebih lanjut dikatakan bahwa tidak adanya standar pelayanan yang jelas membuat praktik pelayanan menjadi sepenuhnya sangat tergantung pada kebaikan hati dan aparat birokrasi 
pelayanan.Tidak adanya standar pelayanan membuat pelayanan publik menjadi penuh dengan ketidak pastian.

Tujuan kebijakan dibentuknya organisasi penyelenggara pelayanan publik menjadi Badan Layanan Umum (BLU) adalah guna peningkatan kinerja pelayanan publik menjadi lebih baik. Perubahan status menjadi BLU diharapkan dapat memperbaiki kinerja penyelenggaraan pelayanan publk, khususnya dalam hal pengelolaan keuangan. BLU diharapkan dapat menyusun anggaran yang beorientasi pada kinerja sehingga dapat memberikan pelayanan kepada masyarakat yang lebih baik. Penganggaran yang beorientasi pada output merupakan praktik yang telah dianut luas oleh pemerintahan modern di berbagai negara. Pendekatan penganggaran yang demikian sangat diperlukan bagi satuan kerja Instansi Pemerintah yang memberikan pelayanan kepada publik. Salah satu alternatif untuk mendorong peningkatan pelayanan public adalah dengan mewirausahakan pemerintah. Mewiraswastakan pemerintah (enterprising the government) adalah paradigma yang memberi arah yang tepat bagi sektor keuangan publik. Ketentuan tentang penganggaran tersebut telah dituangkan dalam UU No. 17 Tahun 2003 tentang Keuangan Negara (Dikutip dari Direktorat Pembinaan Pengelolaan Keuangan Badan Layanan Umum).

Poltekkes Kementerian Kesehatan merupakan intansi pemerintah yang menyelenggarakan pendidikan terhadap tenaga kesehatan yang harus dikelola secara professional dan 13 ( Tiga belas ) Poltekkes Kementerian Kesehatan sejak tahun 2010 telah ditetapkan menjadi Instansi yang menerapkan Pola Pengelolaan Keuangan Badan Layanan Umum salah satunya Poltekkes Kemenkes Surakarta. Dengan telah ditetapkannya Poltekkes Kementerian Kesehatan menjadi Instansi Badan layanan Umum oleh Menteri Keuangan, maka Poltekkes Kementerian Kesehatan harus berusaha menjalankan organisasi yang dikelola secara bisnis yang sehat Dalam rangka mewujudkan konsep bisnis yang sehat, Poltekkes harus senantiasa meningkatkan efisiensi dan produktivitas, antara lain dengan kewenangan merencanakan dan menetapkan kebutuhan sumber daya yang dibutuhkan.

Peran Budaya organisasi akan membentuk identitas organisasi atau jati diri organisasi. Identitas organisasi sangat diperlukan untuk menumbuhkan kebanggaan yang akan mengembangkan budaya kerja. Budaya kerja yang terbentuk secara solid di dalam tubuh organisasi tidak hanya meningkatkan kinerja organisasi tetapi juga membentuk citra baik organisasi. Suatu budaya yang kuat ditandai oleh nilai-nilai inti organisasi yang dipegang kukuh dan disepakati secara luas. Semakin banyak anggota organisasi yang menerima nilai-nilai inti dan semakin besar komitmen mereka terhadap nilai-nilai tersebut, semakin kuat suatu budaya. Sejalan dengan defenisi ini, suatu budaya yang kuat jelas sekali akan memiliki pengaruh yang besar dalam sikap anggota organisasi dibandingkan dengan budaya yang lemah. Hasil spesifik dari suatu budaya yang kuat adalah keluar masuknya pekerja yang rendah. Suatu budaya yang kuat akan memperlihatkan kesepakatan yang tinggi mengenai tujuan organisasi diantara anggota-anggotanya. Budaya Organisasi merupakan sebuah karakteristik yang dijunjung tinggi oleh anggota organisasinya dan dapat sebagai pembeda antara satu organisasi dengan organisasi yang lain. Budaya organisasi merupakan satu kesatuan pandangan yang menciptakan keseragaman 
berperilaku atau bertindak oleh anggota organisasinya dan dapat dirasakan manfaatnya dalam memberi kontribusi bagi efektivitas organisasi secara keseluruhan.

Dalam kehidupan berorganisasi, pemimpin memegang peranan yang sangat penting bahkan sangat menentukan dalam usaha mencapai tujuan organisasi. Seorang pemimpin dalam melakukan aktivitasnya memerlukan sekelompok orang lain yang disebut bawahan. Merekalah yang dikendalikan, dipengaruhi dan digerakkan agar mau bekerja secara efektif dan efesien sesuai dengan keinginan pemimpin Keberadaan pemimpin yang efektif dan dinamis dalam struktur organisasi sangat strategis. Karena dengan adanya komitmen yang tinggi dari seorang pemimpin untuk meningkatkan kualitas para bawahannya. Pemimpin yang efektif dan dinamis akan mampu mengendalikan, mengarahkan dan memotivasi bawahannya kearah tercapainya kinerja karyawan, seperti yang diharapkan oleh pemimpin dalam mencapai sesuatu (Robinson, 2003).

Pegawai sebagai penggerak operasi organisasi, jika kinerja pegawai baik, maka kinerja organisasi juga akan meningkat. Banyak variabel yang mempengaruhi kinerja pegawai salah satunya budaya organisasi. Budaya organisasi sebagai persepsi umum yang dimiliki oleh seluruh anggota organisasi, sehingga setiap pegawai yang menjadi anggota organisasi akan mempunyai nilai, keyakinan dan perilaku sesuai dengan organisasi (Susanto:2008). Berdasarkan hasil penelitian Allysa 2012, menyimpulkan bahwa ada hubungan yang positif antara motivasi berprestasi dan pencapaian prestasi. Artinya manajer yang mempunyai motivasi berprestasi tinggi cenderung memiliki prestasi kerja yang tinggi, dan sebaliknya jika mereka yang prestasi kerjanya rendah dimungkinkan karena motivasi berprestasi yang rendah (Anwar P.M.,2004).

Oleh sebab itu peneliti ingin mengetahui Peran Budaya Organisasi Terhadap Kebijakan Badan Layanan Umum dan Motivasi Kerja Pegawai di Poltekkes Kemenkes yang telah menerapkan Pola Pengelolaan Keuangan Badan Layanan Umum yaitu di Poltekkes Kementerian Kesehatan Surakarta Jawa Tengah

\section{KAJIAN LITERATUR}

\subsection{Budaya Organisasi}

Budaya organisasi adalah sebuah sistem makna bersama yang dianut oleh para anggota yang membedakan suatu organisasi dari organisasi-organisasi lainnya.

Budaya organisasi adalah sistem yang dipercayai dan nilai yang dikembangkan oleh organisasi dimana hal itu menuntun perilaku dari anggota organisasi itu sendiri. Menurut Wood dkk (2001), Budaya organisasi adalah cara-cara berpikir, berperasaan dan bereaksi berdasarkan pola-pola tertentu yang ada dalam organisasi atau yang ada pada bagianbagian organisasi.

Budaya Organisasi adalah sebuah karakteristik yang dijunjung tinggi oleh organisasi dan menjadi panutan organisasi sebagai pembeda antara satu organisasi dengan organisasi yang lain atau budaya organisasi juga diartikan sebagai nilai - nilai dan norma perilaku yang diterima dan dipahami secara bersama oleh anggota organisasi sebagai dasar dalam aturan perilaku yang terdapat dalam organisasi tersebut. 


\subsection{Kepemimpinan}

Kepemimpinan Adalah kemampuan yang dipunyai seseorang untuk memepengaruhi orang-orang lain agar bekerja mencapai tujuan dan sasaran. Kepemimpinan itu adalah suatu proses dimana pimpinan digambarkan akan memberi perintah atau pengarahan, bimbingan atau mempengaruhi pekerjaan orang lain dalam memilih dan mencapai tujuan yang telah ditetapkan.

Menurut Moejiono (2002) kepemimpinan dimana menurut moejiono bahwa kepemimpinan adalah sebagai akibat penagaruh satu arah, karena pemimpin mungkin memiliki kualitas-kualitas tertentu yang membedakan dirinya dengan pengikutnya.

Pemimpin yang efektif adalah seorang pemimpin yang dapat mempengaruhi orang lain agar dapat bekerja sama untuk mencapai hasil yang memuaskan bagi terjadinya perubahan yang bermanfaat.

\subsection{Motivasi Kerja}

Menurut Kamus Besar Bahasa Indonesia, motivasi adalah dorongan yang timbul pada diri seseorang secara sadar atau tidak sadar untuk melakukan suatu tindakan dengan tujuan tertentu. Kerja adalah kegiatan melakukan sesuatu. Jadi motivasi kerja adalah dorongan yang timbul pada diri seseorang secara sadar atau tidak sadar untuk melakukan suatu pekerjaan.

Motivasi kerja didefinisikan sebagai sesuatu yang menimbulkan semangat atau dorongan kerja. Menurut Robbins (2007) motivasi didefinisikan sebagai kesediaan untuk mengeluarkan tingkat upaya yang tinggi untuk tujuan-tujuan organisasi yang dikondisikan oleh kemampuan upaya itu untuk memenuhi sesuatu kebutuhan individu. Ketiga unsur kunci dalam definisi ini adalah upaya, tujuan, dan kebutuhan. Menurut Samsudin (2005) memberikan pengertian motivasi sebagai proses mempengaruhi atau mendorong dari luar terhadap seseorang atau kelompok kerja agar mereka mau melaksanakan sesuatu yang telah ditetapkan.

Faktor yang akan mempengaruhi motivasi kerja pegawai meliputi: (1). Faktor kebijakan organisasi. Melipui gaji, tunjangan, dan pensiun. Dampaknya terhadap motivasi kerja biasanya hanya sekedar untuk bertahan. Tidak memberikan dampak yang begitu besar dalam peningkatakn kinerja. Jadi, tidak cukup hanya mengandalkan masalah gaji, pensiun, dan tunjangan untuk memotivasi karyawan untuk mendapatkan kinerja terbaik. (2). Faktor imbalan atau reward. Jika dikelola dengan baik, sistem imbalan atau reward terhadap karyawan yang berprestasi akan memberikan dampak yang besar untuk peningkatan motivasi. (3). Faktor Budaya organisasi. dapat memberikan dampak yang besar dalam peningkatan motivasi kerja pegawai. Budaya yang mengedepankan rasa hormat, kebersamaan, kejujuran, dan keakraban akan meningkatkan motivasi kerja cukup signifikan. .(4). Faktor kondisi mental Badan Layanan Umum (BLU).

Adalah instansi di lingkungan pemerintah yang dibentuk untuk memberikan pelayanan kepada masyarakat berupa penyediaan barang dan atau jasa yang dijual tanpa 
mengutamakan mencari keuntungan dan dalam melakukan kegiatannya didasarkan pada prinsip efisiensi dan produktivitas. Berdasar PP no: 23 tahun 2005 tentang Pengelolaan Keuangan Badan Layanan Umum, tujuan BLU adalah meningkatkan pelayanan kepada masyarakat dalam rangka memajukan kesejahteraan umum dan mencerdaskan kehidupan bangsa dengan memberikan fleksibilitas dalam pengelolaan keuangan berdasarkan prinsip ekonomi dan produktivitas dan penerapan praktik bisnis yang sehat. Secara umum asas badan layanan umum adalah pelayanan umum yang pengelolaannya berdasarkan kewenangan yang didelegasikan, tidak terpisah secara hukum dari instansi induknya. Pola Pengelolaan Keuangan Badan Layanan Umum, yang selanjutnya disebut PPK-BLU, adalah pola pengelolaan keuangan yang memberikan fleksibilitas berupa keleluasaan untuk menerapkan praktek-praktek bisnis yang sehat untuk meningkatkan pelayanan kepada masyarakat dalam rangka memajukan kesejahteraan umum dan mencerdaskan kehidupan bangsa. Rencana Bisnis dan Anggaran BLU, yang selanjutnya disebut RBA, adalah dokumen perencanaan bisnis dan penganggaran yang berisi program, kegiatan, target kinerja, dan anggaran suatu BLU. Standar Pelayanan Minimum adalah spesifikasi teknis tentang tolok ukur layanan minimum yang diberikan oleh BLU kepada masyarakat. Praktek bisnis yang sehat adalah penyelenggaraan fungsi organisasi berdasarkan kaidahkaidah manajemen yang baik dalam rangka pemberian layanan yang bermutu dan berkesinambungan. BLU bertujuan untuk meningkatkan pelayanan kepada masyarakat dalam rangka memajukan kesejahteraan umum dan mencerdaskan kehidupan bangsa dengan memberikan fleksibilitas dalam pengelolaan keuangan berdasarkan prinsip ekonomi dan produktivitas, dan penerapan praktek bisnis yang sehat.

Karakteristik khusus yang membedakan antara Badan Layanan Umum dengan unit organisasi atau institusi pemerintah lainnya, yakni: (1). BLU merupakan instansi pemerintah yang menyediakan barang dan jasa yang bersentuhan langsung dengan masyarakat. Oleh karena BLU menyediakan barang dan jasa kepada masyarakat maka ada pendapatan yang diperoleh oleh BLU dari biaya yang dibebankan kepada konsumennya. (2). BLU harus menjalankan praktek bisnis yang sehat tanpa mengutamakan pencarian keuntungan. Ini karakteristik yang sangat spesial sekali karena instansi pemerintah diperkenankan untuk menerapkan praktek bisnis seperti dalam yang umum dilakukan oleh dunia bisnis/swasta. Akan tetapi walaupun diselenggarakan sebagaimana institusi bisnis, BLU tidak diperkenankan mencari keuntungan (not-for-profit). (3). BLU dijalankan dengan prinsip efisien dan produktivitas. Karakteristik ini jauh berbeda dari instansi pemerintah biasa yang dalam penyelenggaraan layanannya mengedepankan kepada penyerapan anggaran yang sangat tinggi, terlepas kegiatan tersebut mencapai sasaran dengan tepat atau tidak. Pada BLU penyerapan anggaran bukanlah target karena surplus/kelebihan anggaran dapat digunakan kembali pada tahun berikutnya untuk peningkatan kualitas layanannya. (4). Adanya fleksibilitas dan otonomi dalam menjalankan operasional BLU, yakni: fleksibilitas dalam hal pengelolaan keuangan, fleksibilitas dalam pengelolaan sumber daya manusia dan fleksibilitas dalam hal pengelolaan dan pengadaan aset/barang. (5). BLU dikecualikan dari ketentuan pengelolaan keuangan negara pada umumnya. 


\section{METODE PENELITIAN}

Penelitian ini menganalisis secara empiris tentang pengaruh. Peran Budaya Organisasi terhadap kebijakan Badan Layanan Umum dan motivasi kerja pegawai pada Poltekkes Kementerian Kesehatan Surakarta Jawa Tengah. Variabel dalam penelitian ini dibagi menjadi 3 (tiga). Variabel independen yaitu Peran budaya organisasi, Efektivitas kepemimpinan dan Motivasi kerja pegawai sedangkan variabel dependen adalah kebijakan Badan Layanan Umum . Penelitian ini menggunakan Simple random sampling yang merupakan suatu teknik sampling yang dipilih secara acak (Sugiyono, 2010). Setiap unsur populasi harus memilik kesempatan sama untuk bisa dipilih menjadi sampel. Pengambilan data dengan menggunakan kuisioner. Penelitian ini akan dilaksanakan di Poltekkes Kementerian Kesehatan Surakarta pada bulan Mei - November 2016.

\section{Kerangka Konsep}

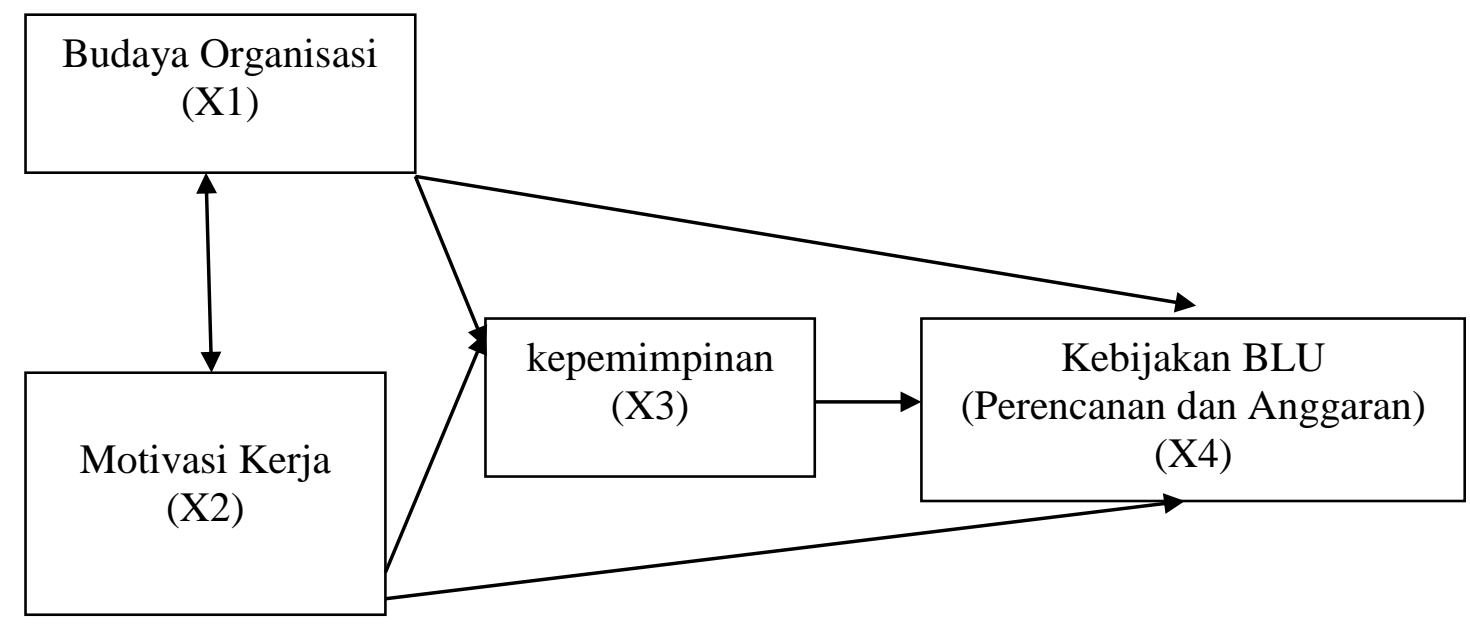

Gambar 1. Kerangka konsep penelitian

\section{Hipotesis}

Adapun hipotesisnya adalah sebagai berikut :

H1: Budaya organisasi berpengaruh positif terhadap kepemimpinan

$\mathrm{H} 2$ : $\quad$ Motivasi kerja berpengaruh positif terhadap kepemimpinan

H3: Motivasi kerja pegawai berpengaruh positif terhadap Kebijakan Badan Layanan Umum

H4: Budaya Organisasi berpengaruh positif terhadap kebijakan badan layanan Umum

H5: Kepemimpinan berpengaruh positif terhadap kebijakan badan layanan Umum

\section{Hasil Penelitian dan Pembahasan}

4.1. Demografi responden 
Dibawah ini disajikan komposisi responden berdasarkan jenis kelamin PNS Poltekkes kemenkes Surakarta dalam Tabel 1. berikut:

Tabel 1. Komposisi Responden Menurut Jenis Kelamin

\begin{tabular}{|lc|c|c|}
\hline & & \multicolumn{2}{|c|}{ Surakarta } \\
\hline & Usia & $\begin{array}{c}\text { Jumlah } \\
\text { Responden }\end{array}$ & $\begin{array}{c}\text { Persentas } \\
\text { e (\%) }\end{array}$ \\
\hline 1. & Laki-laki & 20 & $40 \%$ \\
\hline 2. & Perempuan & 30 & $60 \%$ \\
\hline & Jumlah & 50 & $100 \%$ \\
\hline
\end{tabular}

Dari Tabel 1 tampak bahwa jenis kelamin yang paling dominan pada poltekkes Surakarta adalah perempuan berjumlah 30 orang (60\%).

Berdasarkan data primer yang dikumpulkan, maka diperoleh profil responden menurut umur sebagai berikut:

Tabel 2. Komposisi Responden Menurut Usia

\begin{tabular}{|l|l|l|}
\hline & \multicolumn{2}{|c|}{ Surakarta } \\
\hline Usia & $\begin{array}{l}\text { Jumlah } \\
\text { Responden }\end{array}$ & $\begin{array}{l}\text { Persentase } \\
(\%)\end{array}$ \\
\hline $21-30$ tahun & 9 & $18 \%$ \\
\hline $31-40$ tahun & 16 & $32 \%$ \\
\hline$>40$ tahun & 25 & $50 \%$ \\
\hline Jumlah & $\mathbf{5 0}$ & $\mathbf{1 0 0} \%$ \\
\hline
\end{tabular}

Dari tabel 2 tampak bahwa kelompok umur paling dominan pada poltekkes Surakarta usia paling dominan adalah pada usia > 40 tahun sebanyak 25 orang atau 50\%. sedangkan kelompok umur terkecil Surakarta adalah 21-30 tahun.

\subsection{Confirmatory Factor Analysis Masing-masing Variabel Laten.}

Analisis faktor konfirmatori ini merupakan tahap pengukuran terhadap dimensidimensi yang membentuk variabel laten dalam model penelitian. Variabelvariabel atau konstruk laten yang digunakan pada model penelitian ini terdiri dari 4 
variabel. Hasil confirmatory factor analysis adalah pengukuran terhadap dimensidimensi yang membentuk variabel laten dalam model penelitian. Hasilnya diringkas sebagai berikut.

Tabel 3. Confirmatory Factor Analysis Budaya Organisasi

\begin{tabular}{|l|l|l|}
\hline Budaya & Dimensi & Suraka \\
\hline \multirow{4}{*}{} & Nilai & 0,364 \\
\cline { 2 - 3 } & Sikap & 0,700 \\
\cline { 2 - 3 } & Penghargaan & 0,847 \\
\hline
\end{tabular}

Menurut Ferdinand (2010) Hasil perhitungan untuk indikator -indikator pembentuk konstruk masih terdapat angka dibawah 0,5. Hasil perhitungan untuk indikator -indikator pembentuk konstruk masih terdapat angka dibawah 0,5. Angkaangka tersebut untuk indikator nilai. Dengan hasil ini, maka dapat dikatakan bahwa indikator pembentuk variabel laten tersebut menunjukkan hasil yang kurang baik.

Tabel 4. Confirmatory Factor Analysis Motivasi Kerja

\begin{tabular}{|l|l|l|}
\hline Motivasi & \multicolumn{1}{|c|}{ Dimensi } & Surakarta \\
\hline \multirow{2}{*}{} & Harapan Pribadi & 0,280 \\
\cline { 2 - 3 } & Prestasi Kerja & 0,701 \\
\hline
\end{tabular}

Hasil perhitungan untuk indikator - indikator pembentuk konstruk masih terdapat angka dibawah 0,5. Angka-angka tersebut untuk indikator harapan pribadi. Dengan hasil ini, maka dapat dikatakan bahwa indikator harapan pribadi pembentuk variabel laten tersebut menunjukkan hasil yang kurang baik

Tabel 5. Confirmatory Factor Analysis kepemimpinan

\begin{tabular}{|l|l|l|}
\hline Kepemimpinan & Dimensi & Surakarta \\
\hline & Mengarahkan & 0,820 \\
\cline { 2 - 3 } & Keteladan & 0,713 \\
\cline { 2 - 3 } & Komunikasi Efektif & 0,738 \\
\hline
\end{tabular}

Dengan hasil ini, maka dapat dikatakan bahwa indikator -indikator pembentuk variabel laten tersebut menunjukkan hasil yang baik. 
Tabel 6. Confirmatory Factor Analysis BLU

\begin{tabular}{|l|l|l|}
\hline BLU & Dimensi & Suraka \\
\hline \multirow{2}{*}{} & Perencanaan Partisipatif & 0,843 \\
\cline { 2 - 3 } & & \\
\cline { 2 - 3 } & Otonomi Anggaran & 0,820 \\
\hline
\end{tabular}

Dengan hasil ini, maka dapat dikatakan bahwa indikator -indikator pembentuk variabel laten tersebut menunjukkan hasil yang baik

\subsection{Analisis Faktor Konfirmatori Konstruk Eksogen}

Hasil pengolahan data untuk analisis faktor konfirmatori konstruk eksogen untuk budaya organisasi dengan motivasi kerja Poltekkes Surakarta adalah sebagai berikut

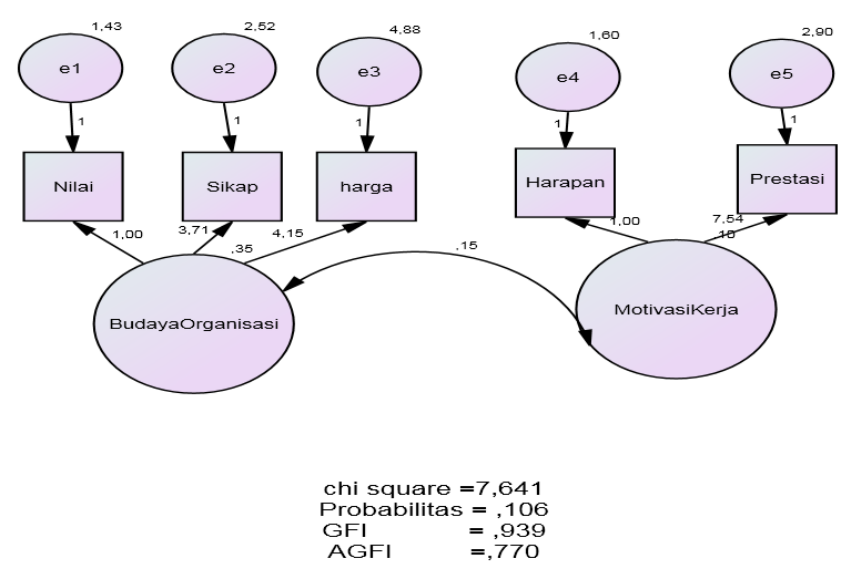

Gambar 1. Confirmatory factor analysis - konstruk

Tabel 7. Confirmatory Factor Analysis Konstruk Eksogen Poltekkes Surakarta

\begin{tabular}{cccc}
$\begin{array}{c}\text { Goodness of Fit } \\
\text { Indeks }\end{array}$ & $\begin{array}{c}\text { Cut-off } \\
\text { Value }\end{array}$ & $\begin{array}{c}\text { Hasil } \\
\text { Analisis }\end{array}$ & $\begin{array}{c}\text { Evaluasi } \\
\text { Model }\end{array}$ \\
\hline Chi - Square & $\leq 9,49$ & 7,641 & Baik \\
RMSEA & $\leq 0.08$ & 0,14 & Marjinal \\
GFI & $\geq 0.90$ & 0,94 & Baik \\
AGFI & $\geq 0.90$ & 0,77 & marjinal \\
TLI & $\geq 0.95$ & 0,82 & Marjinal \\
CFI & $\geq 0.95$ & 0,96 & Baik
\end{tabular}


Hasil terlihat bahwa semua konstruk yang digunakan untuk membentuk sebuah model penelitian, pada proses analisis faktor konfirmatori telah memenuhi kriteria goodness of fit yang telah ditetapkan. Nilai chi square pada analisis ini menunjukkan nilai lebih kecil dari nilai cut off sebesar 7,64 $<9,49$ dengan demikian nilai probabilitasnya $(\mathrm{p}>0.05)$, nilai ini menunjukkan tidak adanya perbedaan antara matriks kovarian sample dengan matriks kovarian populasi yang diestimasi.

Hasil pengujian terhadap nilai-nilai muatan faktor (loading faktor) untuk masingmasing indikator diperoleh sebagai berikut

Tabel 8. Confirmatory Factor Analysis Konstruk Eksogen Poltekkes Surakarta

Estimate S.E. C.R. P Label

\begin{tabular}{lcccccc}
\hline Nilai & $<---$ & Budaya Organisasi & 1,000 & & & \\
Sikap & $<---$ & Budaya Organisasi & 3,711 & 1,334 & 2,782 &, 005 W1 \\
Harga & $<---$ & Budaya Organisasi & 4,148 & 1,506 & 2,754 &, $006 \mathrm{~W} 2$ \\
Harapan & $<---$ & MotivasiKerja & 1,000 & & & \\
& & & & & & \\
Prestasi & $<---$ & MotivasiKerja & 7,536 & 6,229 & 1,210 &, $226 \mathrm{~W} 3$
\end{tabular}

Dari pengolahan data diatas dapat juga terlihat, bahwa setiap indikator atau dimensi pembentuk masing-masing variabel laten menunjukkan hasil yang baik, yaitu nilai CR diatas 1,96. Tetapi ada nilai CR yang berada dibawah 1,96 yaitu hubungan antara motivasi kerja terhadap prestasi yaitu 1,210. Hampir Semua nilai probabilitas untuk masing-masing indikator lebih kecil dari 0,05. Dengan hasil ini, maka dapat dikatakan bahwa indikator-indikator pembentuk variabel laten konstruk telah menunjukkan sebagai indikator yang kuat dalam pengukuran varibel laten. Selanjutnya berdasarkan analisis faktor konformatori ini, maka model penelitian ini dapat digunakan untuk analisis selanjutnya tanpa modifikasi atau penyesuaian.

\subsection{Analisis Faktor Konfirmatori Konstruk Endogen}

Variabel-variabel laten atau konstruk endogen terdiri dari 2 variabel laten dengan 19 dimensi pertanyaan. Hasil pengolahan data untuk analisis faktor konfirmatori konstruk endogen adalah sebagai berikut: 


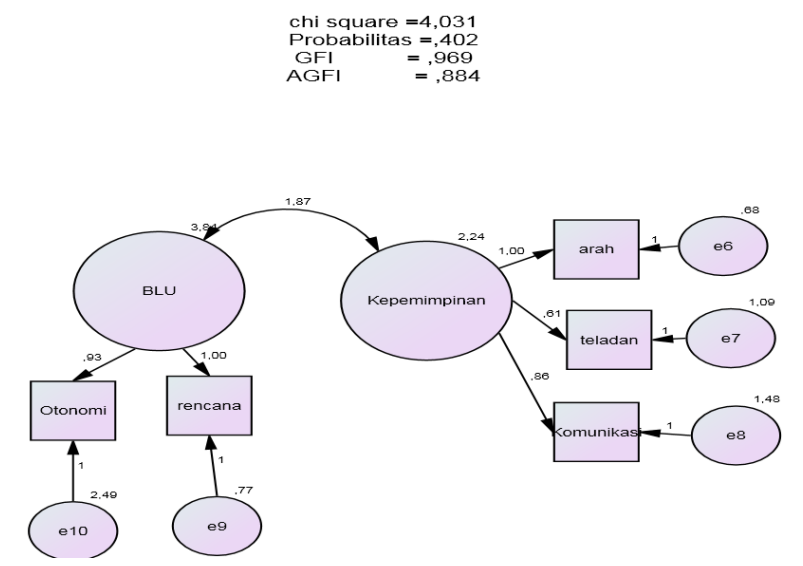

Gambar 2. Confirmatory factor analysis - konstruk endogen

Ringkasan uji kelayakan model confirmatory factor analysis konstruk endogen tersebut adalah sebagai berikut :

\section{Tabel 9. Confirmatory Factor Analysis Konstruk Endogen Poltekkes Surakarta}

\begin{tabular}{cccc}
$\begin{array}{c}\text { Goodness of Fit } \\
\text { Indeks }\end{array}$ & Cut-off Value & Hasil Analisis & $\begin{array}{c}\text { Evaluasi } \\
\text { Model }\end{array}$ \\
\hline Chi - Square & $\leq 9,46$ & 4,03 & Baik \\
RMSEA & $\leq 0.08$ & 0.07 & Baik \\
GFI & $\geq 0.90$ & 0,97 & Baik \\
AGFI & $\geq 0.90$ & 0,88 & Marjinal \\
TLI & $\geq 0.95$ & 0.99 & Baik \\
CFI & $\geq 0.95$ & 1,00 & Baik
\end{tabular}

Hasil analisis pengolahan data terlihat bahwa semua konstruk yang digunakan untuk membentuk sebuah model penelitian, pada proses analisis faktor konfirmatori telah memenuhi kriteria goodness of fit yang telah ditetapkan. Nilai chi square pada analisis ini menunjukkan nilai lebih kecil dari nilai cut off sebesar 4,03 < 9,46 dengan demikian nilai probabilitasnya $(\mathrm{p}>0.05)$, nilai ini menunjukkan tidak adanya perbedaan antara matriks kovarian sample dengan matriks kovarian populasi yang diestimasi.

Tabel 10. Confirmatory Factor Analysis Konstruk Endogen

\begin{tabular}{llllllll} 
& & & Estimate & S.E. & C.R. & P & Label \\
\hline arah & $<---$ & Kepemimpinan & 1,000 & & & & \\
teladan & $<---$ & Kepemimpinan &, 607 &, 137 & 4,426 & $* * *$ & W4 \\
Komunikasi & $<---$ & Kepemimpinan &, 855 &, 176 & 4,848 & $* * *$ & W5 \\
Rencana & & BLU & 1,000 & & & &
\end{tabular}




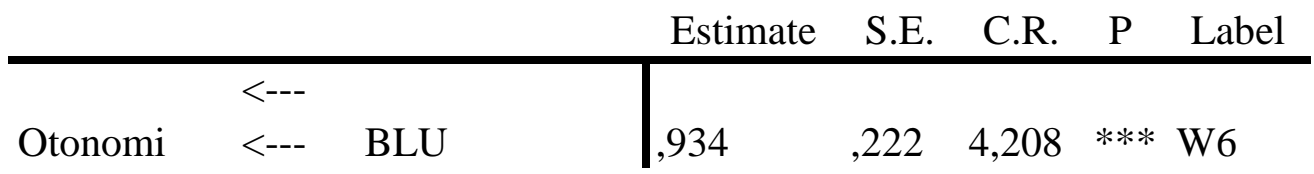

Dari pengolahan data diatas dapat juga terlihat, bahwa setiap indikator atau dimensi pembentuk masing-masing variabel laten menunjukkan hasil yang baik, yaitu nilai CR diatas 1,96. Semua nilai probabilitas untuk masing-masing indikator lebih kecil dari 0,05. Dengan hasil ini, maka dapat dikatakan bahwa indikator-indikator pembentuk variabel laten konstruk telah menunjukkan sebagai indikator yang kuat dalam pengukuran varibel laten. Selanjutnya, berdasarkan analisis faktor konfirmatori ini, maka model penelitian ini dapat digunakan untuk analisis selanjutnya tanpa modifikasi atau penyesuaian-penyesuaian.

\subsection{Analisis Full Model-Structural Equation Model}

Analisis hasil pengolahan data pada tahap full model SEM dilakukan dengan melakukan uji kesesuaian dan uji statistik. Hasil pengolahan data untuk analisis full model SEM ditampilkan pada Gambar 3.

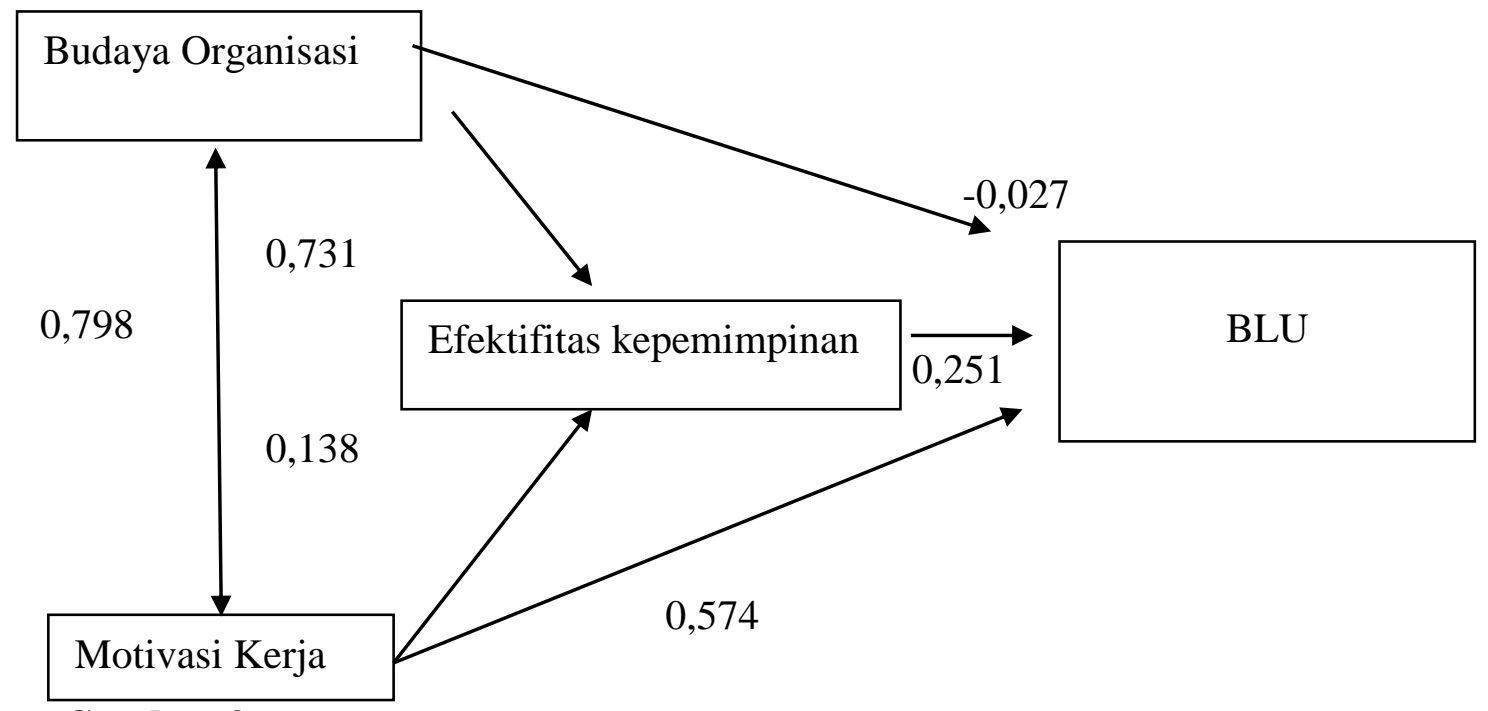

Gambar 3. Hasil Pengujian Full Model-Structural Equation Model (SEM)

Uji terhadap kelayakan model menunjukkan bahwa model ini sesuai dengan data atau fit terhadap data yang digunakan dalam peneliti an adalah seperti telihat pada tabel berikut ini:

Uji terhadap kelayakan model menunjukkan bahwa model ini sesuai dengan data atau fit terhadap data yang digunakan dalam penelitian adalah seperti telihat pada tabel berikut ini: 
Tabel 11. Structural Equation Model

\begin{tabular}{cccc}
$\begin{array}{c}\text { Goodness of Fit } \\
\text { Indeks }\end{array}$ & Cut-off Value & $\begin{array}{c}\text { Hasil } \\
\text { Analisis }\end{array}$ & Evaluasi Model \\
\hline Chi - Square & $\leq 42,56$ & 31,24 & Baik \\
RMSEA & $\leq 0.08$ & 0,05 & Baik \\
GFI & $\geq 0.90$ & 0,90 & Baik \\
AGFI & $\geq 0.90$ & 0,81 & Marjinal \\
TLI & $\geq 0.95$ & 0.98 & Baik \\
CFI & $\geq 0.95$ & 0.99 & Baik \\
Chi square / df & $\leq 2.00$ & 1,07 & Baik
\end{tabular}

Hasil analisis pengolahan data terlihat bahwa semua konstruk yang digunakan untuk membentuk sebuah model penelitian, pada proses analisis full model SEM telah memenuhi kriteria goodness of fit yang telah ditetapkan. Nilai chi square hasil perhitungan lebih kecil dari nilai chi square cut off atau 32,43 $\leq 42,56$ dengan demikian nilai probability pada analisis ini menunjukkan nilai diatas batas signifikansi yaitu sebesar ( $\mathrm{p}>0.05)$. Nilai ini menunjukkan tidak adanya perbedaan antara matriks kovarian prediksi dengan matriks kovarian yang diestimasi. Ukuran goodness of fit lain juga menunjukkan pada kondisi yang baik. Untuk mendapatkan model yang baik, akan terlebih dahulu diuji masalah penyimpangan terhadap asumsi SEM.

\subsection{Evaluasi Normalitas Data}

Asumsi normalitas data diuji dengan melihat nilai skewness dan kurtosis dari data yang digunakan. Apabila nilai CR pada skewness maupun kurtosis data berada pada rentang antara \pm 2.58 , maka data masih dapat dinyatakan berdistribusi pada tingkat signifikansi 0,01 . Hasil pengujian normalitas data ditampilkan pada Tabel 5.15. Tabel ini dapat dilihat pada lampiran III dengan tabel_Assessment of normality (Group number 1)

Tabel 12. Assessment of Normality

\begin{tabular}{l|llllll} 
Variable & $\min$ & $\max$ & skew & c.r. & kurtosis & c.r. \\
\hline Otonomi & 11,000 & 22,000 &,- 573 & $-1,654$ &,- 166 &,- 240 \\
Rencana & 3,000 & 12,000 &,- 385 & $-1,112$ &, 353 &, 510 \\
Komunikasi & 4,000 & 12,000 &,- 238 &,- 686 &, 425 &, 613
\end{tabular}




\begin{tabular}{|c|c|c|c|c|c|c|}
\hline Variable & $\min$ & $\max$ & skew & c.r. & kurtosis & c.r. \\
\hline Teladan & 5,000 & 11,000 &,- 476 & $-1,373$ &, 374 &, 540 \\
\hline Arah & 6,000 & 16,000 &,- 843 & $-2,435$ & 2,196 & 3,169 \\
\hline Prestasi & 25,000 & 37,000 &,- 698 & $-2,015$ & ,223 & ,322 \\
\hline Harapan & 5,000 & 12,000 &,- 323 &,- 933 & 1,188 & 1,715 \\
\hline Harga & 13,000 & 28,000 &,- 981 & $-2,832$ &, 850 & 1,227 \\
\hline Sikap & 8,000 & 23,000 & $\begin{array}{l}- \\
1,734\end{array}$ & $-5,006$ & 4,795 & 6,921 \\
\hline Nilai & 2,000 & 8,000 & $\begin{array}{l}- \\
1,946\end{array}$ & $-5,619$ & 4,009 & 5,787 \\
\hline Multivariate & & & & & 21,789 & 4,973 \\
\hline
\end{tabular}

Hasil pengujian normalitas data sebagaimana pada Tabel 12 menunjukkan bahwa sedikit saja nilai yang terdapat nilai C.R. untuk skewness dan kurtosis yang berada diluar rentang + 2.58. Nilai +2.58 ini diambil dengan melihat nilai $\mathrm{Z}$ dengan tingkat kepercayaan $99 \%$ (Singgih, 2015). Meski ada yang mendapat nilai C.R melebihi ketentuan tetapi nilai skewness dan kurtosisnya masih dibatas ambang +2.58 . Dengan demikian maka data penelitian yang digunakan telah memenuhi persyaratan normalitas data, atau dapat dikatakan bahwa data penelitian telah terdistribusi normal. Dengan demikian asumsi data yang normal dalam hal ini dapat terpenuhi.

\subsection{Evaluasi atas Outlier}

Evaluasi terhadap multivariate outliers dilakukan dengan mengevaluasi nilai jarak Mahalonobis (Mahalonobis Distance) untuk tiap-tiap observasi (Hair, et al 1995 dalam Ferdinand, 2002).

Tabel 13. Pengujian outlier Multivariate

\begin{tabular}{|c|ccc|}
\hline Observation number & Mahalanobis d-squared & p1 & p2 \\
\hline 50 & 31,557 &, 000 &, 023 \\
11 & 24,143 &, 007 &, 051 \\
13 & 20,755 &, 023 &, 106 \\
\hline
\end{tabular}

Tabel tersebut menunjukkan 1 buah sampel dengan nilai jarak mahalonobis terbesar (d-square terbesar). Baris tersebut adalah no baris atau responden 50. Dengan demikian nomor tersebut bisa dihilangkan. Menurut Singgih (2015) data-data yang outlier bisa dipertahankan. Meskipun outlier data tersebut merupakan fakta yang didapat dan mencerminkan hal-hal yang berkaitan dengan riset.

Dari hasil pengolahan data dapat diketahui bahwa yang mempunyai nilai mahalanobis berjumlah sangat sedikit jika dibanding dengan total responden. Jadi dalam analisis ini tidak tidak diperlukan ekslusi terhadap data sampel. 


\subsection{Evaluasi atas Multicollinearity dan singularity}

Pengujian data selanjutnya adalah untuk melihat apakah terdapat multikolinearitas dan singularitas dalam sebuah kombinasi variabel. Indikasi adanya multikolinearitas dan singularitas dapat diketahui melalui nilai determinan matriks kovarians yang benar-benar kecil, atau mendekati nol. Dari hasil pengolahan data nilai determinan matriks kovarians sample adalah :

\section{Determinant of sample covariance matrix $=10637,003$}

Dari hasil pengolahan data tersebut dapat diketahui nilai determinan matriks kovarians sample berada jauh dari nol. Dengan demikian dapat dikatakan bahwa data penelitian yang digunakan tidak terdapat multikolinearitas dan singularitas.

\subsection{Pengujian Hipotesis}

Hasil analisis SEM sebagai langkah pengujian hipotesis adalah sebagai berikut :

Tabel 14. Uji Hipotesis

\begin{tabular}{|c|c|c|c|c|c|c|c|}
\hline & & & Estimate & S.E. & C.R. & $\mathrm{P}$ & Label \\
\hline Kepemimpinan & $<--$ & BudayaOrganisasi & 1,564 & 5,060 & ,309 &, 757 & W9 \\
\hline Kepemimpinan & $<--$ & MotivasiKerja & 1,231 & 7,024 &, 175 &, 861 & W10 \\
\hline BLU & $<--$ & BudayaOrganisasi & $-8,665$ & 49,115 &,- 176 &, 860 & W7 \\
\hline BLU & $<--$ & MotivasiKerja & 15,914 & 76,458 & ,208 &, 835 & W8 \\
\hline BLU & $<--$ & Kepemimpinan &,- 082 & 2,956 &,- 028 & ,978 & W11 \\
\hline
\end{tabular}

\section{Pengujian Hipotesis 1}

Parameter estimasi hubungan antara Budaya organisasi terhadap kepemimpinan diperoleh sebesar 0,757. Pengujian hubungan kedua variabel tersebut menunjukkan nilai C.R $=0,309$ dengan probabilitas $=0,757(\mathrm{p}>0,05)$. Jadi dapat disimpulkan bahwa budaya organisasi tidak berpengaruh positif terhadap kepemimpinan.

\section{Pengujian Hipotesis 2}

Parameter estimasi hubungan antara motivasi kerja terhadap kepemimpinan diperoleh sebesar 0,861. Pengujian hubungan kedua variabel tersebut menunjukkan nilai C.R $=0,175$ dengan probabilitas $=0,861(p>0,05)$. Jadi dapat disimpulkan bahwa 
motivasi tidak berpengaruh terhadap kepemimpinan.

\section{Pengujian Hipotesis 3}

Parameter estimasi hubungan antara motivasi kerja terhadap kebijakan BLU diperoleh sebesar 0,835 . Pengujian hubungan kedua variabel tersebut menujukkan nilai C.R $=0,208$ dengan probabilitas $=0,835(\mathrm{p}>0,05)$. Jadi, dapat diambil kesimpulan bahwa tidak ada hubungan antara motivasi kerja dan kebijakan BLU. Dengan demikian hipotesis 3 ti d a k diterima.

\section{Pengujian Hipotesis 4}

Parameter estimasi hubungan antara budaya organisasi terhadap kebijakan BLU diperoleh sebesar 0,860. Pengujian hubungan kedua variabel tersebut menujukkan nilai C.R $=-0,176$ dengan probabilitas $=0,860(\mathrm{p}>0,05)$. Jadi, dapat diambil kesimpulan bahwa tidak ada hubungan antara budaya organisasi dan kebijakan BLU. Dengan demikian hipotesis $4 \mathrm{tidak}$ diterima

\section{Pengujian Hipotesis 5}

Parameter estimasi hubungan antara kepemimpinan terhadap kebijakan BLU diperoleh sebesar 0, 978. Pengujian hubungan kedua variable tersebut menujukkan nilai C.R $=-0,028$ dengan probabilitas $=0,978(\mathrm{p}>0,05)$. Jadi, dapat diambil kesimpulan mengenai hipotesis 5 yang menyatakan bahwa kepemimpinan tidak berpengaruh positif terhadap kebijakan BLU tidak diterima.

Dari pengujian hipotesis diatas hampir semua tidak ada korelasinya hal ini karena pegawai Poltekes kemenkes Surakarta hampir sebagian besar berstatus PNS. Dengan status tersebut para pegawai merasa bahwa yang memberikan gaji adalah pemerintah. Jadi meskipun berstatus BLU tetapi secara umum tidak berdampak.

\section{SIMPULAN DAN SARAN}

\subsection{Simpulan}

a. Tidak ada hubungan signifikan positif antara budaya organisasi dan kepemimpinan pada Poltekkes Surakarta.

b. Tidak ada hubungan signifikan antara budaya organisasi terhadap kebijakan BLU Poltekkes Surakarta

c. Tidak ada hubungan signifikan antara motivasi kerja terhadap kepemimpinan pada Poltekkes Surakarta

d. Tidak ada hubungan signifikan antara motivasi kerja terhadap kebijakan BLU pada Poltekkes Surakarta

e. Tidak Ada hubungan signifikan positif antara kepemimpinan terhadap kebijakan BLU pada Poltekkes Surakarta 


\subsection{Saran}

Dari hasil pengolahan data yang dilakukan dengan SEM, terdapat 2 kriteria dalam model yang berada pada penilaian marginal yaitu AGFI $(0,81)$ kedepannya perlu dipirkan untuk meminimalkan penyebabnya. Adanya keterbatasan waktu karena padatnya jam kerja pada PNS Poltekkes Kemenkes sebagai sumber informasi sehingga data yang di peroleh tidak maksimal untuk itu perlu dicari waktu yang tepat. Perluasan penelitian yang disarankan dari penelitian ini adalah menambah variabel independen yang mempengaruhi kebijakan BLU Selain itu indikator-indikator penelitian yang digunakan dalam penelitian dapat ditambah dengan indikator-indikator lain diluar penelitian ini yang relevan dengan penelitian yang akan dilakukan. Hal lain yang dapat dilakukan adalah menambah jumlah responden untuk meningkatkan nilai AGFI agar tidak menunjukkan hasil yang baik

\section{DAFTAR PUSTAKA}

A.B Susanto, Dkk. 2008. A strategic Management Approach Culture. The Jakarta Consulting Group. Jakarta.

Allysa Laura Jeyne Ghanie. 2012. "Analisis Pengaruh Budaya Organisasi dan Motivasi Kerja Terhadap Kepuasan Kerja Karyawan Serta Dampaknya Terhadap Kinerja Karyawan PT. Asuransi Astra Buana

Anwar PM. 2004. Manajemen Sumber Daya Manusia Perusahaan. Bandung. PT Remaja Rosdakarya.

Dwiyanto, Agus, 2010, Manajemen Pelayanan Publik: Peduli, Inklusif, dan Kolaboratif. UGM Press, Yogyakarta.

Ferdinand, Agusty, 2006, "Structural Equation Modelling Dalam PenelitianManajemen", Edisi 4, badan Penerbit Universitas Diponegoro, Semarang

Imam, Moejiono, 2002, “Kepemimpinan dan Keorganisasian”, Yogjakarta, UII Press

Robbins, Stephen P. (2003). Perilaku Organisasi. Jakarta: Indeks (2007). Perilaku Organisasi. Jakarta: Salemba 4

Samsudin. 2005. Manajemen Sumber Daya Manusia. Bandung Pustaka Setia 
Sugiyono. 2010. Metode Penelitian Pendidikan Pendekatan Kuantitatif, Kualitatif, dan R\&D. Bandung: Alfabeta

Wood. dkk. 2001. Pola Budaya Organisasi. PT. Inti Indayu. Jakarta

PP No: 23 tahun 2005 tentang Pengelolaan Keuangan Badan Layanan Umum. 